Katarzyna Dubas-Jakóbczyk ${ }^{1}$

ORIGINAL PAPER

Ewa Kocot ${ }^{1}$

Michat Seweryn ${ }^{1}$

Magdalena Koperny ${ }^{2}$

\title{
PRODUCTION LOST DUE TO CERVICAL CANCER IN POLAND IN 2012
}

\author{
PRODUKCJA UTRACONA Z POWODU WYSTĘPOWANIA NOWOTWORU SZYJKI MACICY W POLSCE W 2012 R.
}

\author{
${ }^{1}$ Jagiellonian University Medical College / Collegium Medicum Uniwersytetu Jagiellońskiego, Kraków, Poland \\ Institute of Public Health, Health Economics and Social Security Department / Instytut Zdrowia Publicznego, Zakład Ekonomiki Zdrowia \\ i Zabezpieczenia Społecznego \\ ${ }^{2}$ Province Sanitary Epidemiological Station of Lesser Poland / Wojewódzka Stacja Sanitarno-Epidemiologiczna w Krakowie, Kraków, Poland
}

\begin{abstract}
Background: Poland has one of the highest cervical cancer mortality rates in Europe. It is related to the problem of late diagnosis and low attendance rate in screening programs. The objective of the study has been to assess the annual production loss due to the cervical cancer morbidity and mortality in Poland in 2012. The outcomes have been to provide comprehensive information on cervical cancer's influence on population's ability to work and its overall economic burden for the society. The study has also provided the methodological framework for disease-related production losses in Polish settings. Material and Methods: The human capital method was used. The production losses were calculated in both monetary and quantitative terms (working days lost) due to 4 following reasons: 1) temporary disability to work, 2) permanent disability, 3) informal care, and 4) mortality. Results: Cervical cancer resulted in approx. 702964 working days lost in 2012 due to absence at work for both patients and care givers and a total number of 957678 working days lost due to patients' mortality. The total value of production lost was assessed at 111.4 million euros. More than $66 \%$ of this value was attributed to women's mortality. Conclusions: The calculation of production lost due to cervical cancer burden provides strong evidence to support adequate health promotion and disease prevention actions. Actions promoting cervical cancer screening should be intensified including workplace health promotion activities. Med Pr 2016;67(3):289-299
\end{abstract}

Key words: screening, cost of illness, indirect costs, cervical neoplasm, gross domestic product (GDP), economic burden

\begin{abstract}
STRESZCZENIE
Wstęp: Polska ma jeden z najwyższych w Europie wskaźników umieralności kobiet z powodu nowotworu szyjki macicy. Niewiele kobiet uczestniczy w programach przesiewowych, a u wielu choroba jest późno diagnozowana. Celem badania było oszacowanie produkcji utraconej z powodu występowania nowotworu szyjki macicy w Polsce w 2012 r., a tym samym ocena wpływu choroby na zdolność populacji do pracy. Analizę można traktować również jako przykład metodyki szacowania strat produkcyjnych z powodu występowania określonej jednostki chorobowej przy wykorzystaniu dostępnych w Polsce danych. Materiał i metody: Wykorzystano metodę kapitału ludzkiego i oszacowano produkcję utraconą z 4 powodów - 1) czasowej niezdolności do pracy, 2) trwałej niezdolności do pracy, 3) opieki członków rodziny nad osobą chorą i 4) umieralności - w kategoriach monetarnych i ilościowych (dni utraconej produkcji). Wyniki: Nowotwór szyjki macicy spowodował w 2012 r. utratę 702964 dni produkcji z powodu chorobowości i 957678 dni z powodu umieralności. Całkowitą produkcję utraconą oszacowano na 111,4 mln euro, z czego ponad 66\% było spowodowanych zgonami osób chorych na nowotwór. Wnioski: Oszacowanie produkcji utraconej z powodu nowotworu szyjki macicy dostarcza silnych argumentów w procesie alokacji zasobów w sektorze zdrowia na rzecz prewencji nowotworów. Należy zintensyfikować również działania z zakresu promocji badań przesiewowych, m.in. z uwzględnieniem roli pracodawcy. Med. Pr. 2016;67(3):289-299
\end{abstract}

Słowa kluczowe: badanie przesiewowe, koszty choroby, koszty pośrednie, nowotwór szyjki macicy, Produkt Krajowy Brutto (PKB), obciążenie ekonomiczne

Corresponding author / Autorka do korespondencji: Katarzyna Dubas-Jakóbczyk, Jagiellonian University Medical College, Institute of Public Health, Health Economics and Social Security Department, Grzegórzecka 20,31-531 Kraków, Poland, e-mail: katarzyna.dubas@uj.edu.pl

Received: September 20, 2015, accepted: December 20, 2015

\section{INTRODUCTION}

Cervical cancer (CC) is one of the most common cancers among women worldwide (with an estimated 500000 cases and an average rate of 300000 deaths occurring per year). In Europe in 2012, 13.4 women per 100000 of the population were diagnosed with CC and 24397 died from it. Poland has one of the highest mortality rates in Europe (7.4 in comparison with the European Union's average rate of 3.9 and 4.7 - for 
Europe in 2012) [1]. In 2012, 1669 women died in Poland due to CC, the majority of whom were of productive age [2].

The calculation of production loss due to specific illnesses has been broadly discussed and presented in literature [3-6]. It constitutes one of the elements of the cost of illness studies which measure the economic burden of a disease and estimate the maximum amount that could potentially be saved or gained if a disease were eradicated [6]. It is also an element of health programs' economic evaluation studies which take a broad, societal perspective. The comprehensive analysis of the cost of illness includes both direct (medical and non-medical) costs as well as values of production losses due to reduced working time (called an indirect cost). An indirect cost is attributed to both morbidity (absenteeism at work due to ill health and presenteeism - that is lower productivity while being present at work) and mortality (potential years of production lost due to death at productive age).

Several studies present the estimation of direct and/ or indirect costs associated with CC in different countries [7-12]. The experts of the American Cancer Society indicate that production losses due to CC may be more than a half of the total costs associated with the cancer [13]. Insinga et al. estimated that the indirect costs of CC in the USA far outweigh the direct costs associated with the diagnosis and treatment of the cancer [9]. Lost production due to CC in Poland in 2009 was estimated in the Macioch and Hermanowski study at the level of 87 million euros, constituting the second largest oncological cause of lost production (following breast cancer) in the female population [14]. Any comparison between the studies is impossible due to different methodological approaches.

\section{Aim of the study}

The aim of this study has been to assess the annual production loss due to CC morbidity and mortality in Poland in 2012. The added value of the presented analysis, in comparison to the previous study (Macioch and Hermanowski [14]), is the presentation of outcomes in both monetary and quantitative terms. Information on the number of working days and/or person-years lost due to CC is presented. The assessment is carried out due to 4 following reasons of production lost:

1. Temporary disability to work.

2. Permanent disability.

3. Informal care.

4. Mortality.
The analysis of quantitative outcomes provides an important insight into how CC affects the population's ability to work and allows for comparisons with different settings/studies. The results are to help understand CC's economic burden on Polish society and thus constitute the evidence to support adequate health promotion and disease prevention actions.

\section{MATERIAL AND METHODS}

The human capital method (HCM) was used to assess production loss due to CC in Poland in 2012. This approach encompasses the societal perspective and estimates an individual's contribution to society by applying a specific productivity measure (examples are: average earnings, gross domestic product (GDP) per person employed, gross added value per capita). It counts any hour not worked due to illness as an hour of production lost $[15,16]$. The choice of the HCM was based on its broad applicability in economic evaluation studies and exploitation of commonly available data.

The analysis included production loss due to:

1. Patients' work absence due to temporary disability (sick leave).

2. Patients' work absence due to permanent disability in the form of reduced hours or workforce departure.

3. Informal care givers' work absence (a carer's leave).

4. Mortality among patients' population of productive age.

The first three from the above categories measure the production loss due to CC morbidity of both patients (1-2) and caregivers (3). The fourth category measures the production loss due to patients' mortality. Regardless of the category, the formula of calculating the production loss was always: 'number of days or years of production lost' multiplied by 'forgone productivity measure.'

While calculating the number of days of patients' work absence due to temporary disability (sick leaves), only working days were included (on average: 5/7 of the total number of days of work absence).

In the case of permanent disability to work - the number of patients benefiting from a social security allowance due to permanent disability to work caused by CC in 2012 was used. Those women represented 2 groups: those with permanent but partial disability and those with complete permanent disability. The first group could be employed on a part-time job basis (CC caused reduced hours of work), whilst the second group had to be dismissed from the workforce resourc- 
es permanently (workforce departure). The value of the social security allowance for women with partial disability is at the level of $75 \%$ of the allowance for women with complete disability. Based on the differences in the allowances' values, it was assumed that in the case of reduced hours of work, the woman may be employed only at the level of $25 \%$ of full time basis (thus the lost production value was calculated as $75 \%$ of the applied measure).

Occurrence of an illness might result in a limited work ability not only for the patient himself/herself but also for the informal carer - mainly a family member. In Poland, family members of a patient may officially apply for the so called 'carer's leave,' that is a justified temporary absence from work (for the time of taking care of the patient). There is no detailed data on the number and duration of a carer's leave per a patient's illness ICD-10 (ICD - the International Statistical Classification of Diseases and Related Health Problems) category. The number of days of informal care givers' absence from work due to taking care of CC patients was assessed based on the proportion of CC sick leaves in the adult population to the total number of sick leaves in 2012. We assumed that the number of days of informal care givers' absence from work due to taking care of CC patients in relation to the total number of days of informal care givers' absence from work is the same as the relation of the number of days of CC patients' absence from work to the total number of all causes of patients' work absence.

Finally, for the purpose of the calculation of production loss due to premature mortality, the following data was included:

while calculating the number of women who would have lived had they not died due to CC, the survival probability rates for women in 2012 at each age were applied with the aim of adjusting for the probability of death from other causes [2];

the retirement age for women who would have lived had they not died from CC in 2012 was applied to the 60-67 years old (depending on the women's age in 2012) according to the Polish pension system legislation [17];

the GDP growth forecast for Poland after the year 2012 was applied according to the European Commission's analysis [18];

the employment rate of women in 2012 was included as well as its projected value per age group after the year 2012, based on the European Commission's analysis $[18,19]$; the present value of all future production losses was calculated using a $5 \%$ discount rate. The choice of the discount rate was based on the Polish Ministry of Health's regulation concerning economic evaluations' basic requirements [20].

The forgone productivity measure applied in the analysis was the gross domestic product (GDP) per person employed. This measure presents the real value of an employee's work, which due to market failures might be higher than the salary he or she receives [21]. The value of the GDP per employee was adjusted by a correction factor ( 0.65 for base analysis) representing production elasticity in respect of a labour factor. As economic growth depends on several production factors (the key ones include labour and capital), diminishing only one of them (labour) influences only a relevant proportion of the GDP. Application of a correction factor allows the adjustment of the GDP per employee value to present its percentage share related only to a labour factor (in this case - hours of work/production lost due to CC morbidity and mortality). It corresponds to the commonly accepted value of the labour percentage share in total income [18].

Summary of all methodological assumptions is presented in the Table 1.

The majority of data for the analysis was obtained from publicly available sources. The data on CC mortality was obtained from the Central Statistical Office's (Główny Urząd Statystyczny - GUS) Demography Database 2014.

The data on the number of sick leaves, the number of days of temporary and permanent disability to work due to CC were obtained from the Social Insurance Institute (Zakład Ubezpieczeń Społecznych - ZUS). Being a part of obligatory social and health insurance schemes and covering a vast majority of the population - ZUS provides data on social insurance benefits consumption, including benefits in the case of temporary or permanent work disability per ICD-10 category. There is also a separate social insurance system for farmers: the Agricultural Social Insurance Fund (Kasa Rolniczego Ubezpieczenia Społecznego KRUS), which covers about $10 \%$ of the total population enjoying the social insurance coverage. The Agricultural Social Insurance Fund does not provide data on sick leave per ICD-10 category, thus the data for farmers was assessed by applying the same CC related work disability benefits proportion as in the case of the general population. All the data was gathered in June 2014. 
Table 1. Parameters included in the methodological assumption for assessment of production lost due to cervical cancer (CC) in Poland, 2012

Tabela 1. Parametry uwzględnione w założeniach metodologicznych szacowania produkcji utraconej z powodu występowania nowotworu szyjki macicy w Polsce w 2012 r.

\begin{tabular}{|c|c|c|}
\hline $\begin{array}{l}\text { Parameter } \\
\text { Parametr }\end{array}$ & $\begin{array}{l}\text { Value } \\
\text { Wartość }\end{array}$ & $\begin{array}{l}\text { References } \\
\text { Piśmiennictwo }\end{array}$ \\
\hline GDP per employee in Poland in 2012 / PKB na 1 pracującego w Polsce w 2012 r. [EUR] & 24466.19 & GUS, 2014 [19] \\
\hline GDP correction factor / Współczynnik korygujący PKB & 0.65 & European Commission, 2009 [21] \\
\hline Working days per year in Poland in $2012^{*} /$ Dni robocze w roku w Polsce w 2012 r. ${ }^{*}$ [n] (M) & 229 & $\begin{array}{l}\text { authors' calculation / oszacowane } \\
\text { przez autorów }\end{array}$ \\
\hline Employment rate of women in Poland in 2012 / Wskaźnik zatrudnienia kobiet w Polsce 2012 r. [\%] & 53.1 & GUS, 2014 [19] \\
\hline $\begin{array}{l}\text { Survival probability rate for women in Poland in } 2012 \text { / Współczynnik przeżywalności kobiet } \\
\text { w Polsce w } 2012 \text { r. }\end{array}$ & $0.9998-0.6757$ & GUS, 2014 [2] \\
\hline $\begin{array}{l}\text { Women retirement age in Poland in } 2012 \text { / Wiek kobiet w momencie przejścia na emeryturę } \\
\text { w Polsce w } 2012 \text { r. [years] }\end{array}$ & $60-67$ & Pensions Act, 2012 [17] \\
\hline GDP growth forecast in Poland after 2012 / Prognoza wzrostu PKB w Polsce po 2012 r. [\%] & $2.38-1.60$ & European Commission, 2011 [18] \\
\hline $\begin{array}{l}\text { Forecast of employment rate of women per age groups in Poland after } 2012 \text { / Prognoza } \\
\text { wskaźnika zatrudnienia kobiet wg grup wiekowych w Polsce po } 2012 \text { r. [\%] }\end{array}$ & $24.4-72.5$ & European Commission, 2011 [18] \\
\hline Discount rate / Stopa dyskontowa [\%] & 5 & MZ, 2012 [20] \\
\hline
\end{tabular}

The calculation of lost production due to the CC in Poland in 2012 included two ICD-10 categories: C.53 malignant neoplasm of cervix uteri (invasive CC) and D.06 - carcinoma in situ of cervix uteri (called the pre-cancer stage or non-invasive CC).

Production loss is presented in both descriptive (number of days/years of production lost) and monetary terms. All monetary values are expressed in terms of euro (constant 2012).

In order to check the robustness of the results, a multivariate sensitivity analysis was performed. It included changes of two factors: the GDP correction factor (to 0.55 and 0.60 with the base value of 0.65 ) and the discount rate (to $0 \%$ and $3 \%$ with the base value $5 \%$ ). The labour factor's percentage share in the national income differs among countries. Some studies indicate that the level of the labour percentage share is lower in the new Member States of the European Union (EU) than in the EU-15 (the average value in Poland in 1992-2006 was estimated to stand at 0.55, while the average rate for the EU-15 was 0.64) [22]. Additionally, the recent research indicates that the labour percentage share is declining in many countries [23]. Therefore, in the framework of the sensitivity analysis, two different, lower values of the GDP correction factor were applied: 0.60 and 0.55 . As for the discount factor, two additional values were also applied (3\% and $0 \%)$. These were the values recommended by the World Health Organization for economic evaluation studies [24].

\section{RESULTS}

The value of the production loss due to the CC in Poland in 2012 is presented in the following four categories:

1. Patients' work absence related to temporary disability (sick leaves) - in 2012 a total number of 5964 sick leaves were issued by doctors due to the CC, which resulted in a total number of 167833 days of temporary work absence (which gives approx. 119881 working days lost). The average duration of sick leave due to the CC was 28.14 days (28.53 days for C.53 and 20.22 days for D.06).

The total value of the production loss due to temporary disability to work was assessed to stand at 8325193.85 euros, the vast majority of which (97\%) was due to the invasive form of the CC (C.53) (Table 2).

2. Patients' work absence related to permanent disability - in 2012, 3135 Polish women benefited from the social security allowance due to permanent disability to work caused by the CC. This number included 531 women with permanent but partial disability (the CC caused reduced hours of work) 
Table 2. Production lost due to cervical cancer (CC) patients' work absence related to temporary disability (sick leaves) in Poland, 2012 Tabela 2. Produkcja utracona z powodu czasowej niezdolności do pracy związanej z przebywaniem na zwolnieniu lekarskim wynikającym z występowania nowotworu szyjki macicy w Polsce w 2012 r.

\begin{tabular}{|c|c|c|}
\hline $\begin{array}{l}\text { ICD- } 10 \text { category } \\
\text { Kategoria ICD-10 }\end{array}$ & $\begin{array}{l}\text { Working days lost } \\
\text { Utracone dni pracy } \\
{[\mathrm{n}]}\end{array}$ & $\begin{array}{c}\text { Production lost }^{\mathrm{a}} \\
\text { Produkcja utracona } \\
\text { [EUR] }\end{array}$ \\
\hline D.06 & 3998 & 277671.47 \\
\hline Total / Ogółem & 119881 & 8325193.85 \\
\hline
\end{tabular}

ICD-10 - International Statistical Classification of Diseases and Related Health Problems / Międzynarodowa Statystyczna Klasyfikacja Chorób i Problemów Zdrowotnych; C.53 - malignant neoplasm of cervix uteri (invasive CC) / nowotwór złośliwy szyjki macicy (inwazyjna forma raka szyjki macicy); D.06 - carcinoma in situ of cervix uteri (called the pre-cancer stage or non-invasive CC) / rak in situ szyjki macicy (nazywany stanem przedinwazyjnym)

${ }^{a}$ Calculated based on the GDP per employee per working day adjusted by the correction factor $(0.65)=69.45$ euros / Obliczono na podstawie PKB na 1 pracującego na 1 dzień roboczy z uwzględnieniem współczynnika korygującego $(0,65)=69,45$ euro.

GDP - as in Table 1 / PKB - jak w tabeli 1.

Table 3. Production lost due to cervical cancer (CC) patients' work absence related to permanent disability in Poland, 2012 Tabela 3. Produkcja utracona z powodu trwałej niezdolności do pracy spowodowanej występowaniem nowotworu szyjki macicy w Polsce w 2012 r.

\begin{tabular}{|c|c|c|c|}
\hline & $\begin{array}{l}\text { ICD- } 10 \text { category } \\
\text { Kategoria ICD-10 }\end{array}$ & $\begin{array}{c}\text { Women } \\
\text { Kobiety } \\
{[\mathrm{n}]}\end{array}$ & $\begin{array}{c}\text { Production lost } \\
\text { Produkcja utracona } \\
\text { [EUR] }\end{array}$ \\
\hline C. 53 & & 523 & $6236753.95^{a}$ \\
\hline sub-total / ogółem & & 531 & $6336656.19^{\mathrm{a}}$ \\
\hline \multicolumn{4}{|c|}{$\begin{array}{l}\text { Permanent disability in the form of workforce departure (complete disability to work) / Trwała niezdolność } \\
\text { do pracy skutkująca brakiem możliwości podjęcia zatrudnienia (całkowita niezdolność do pracy) }\end{array}$} \\
\hline C. 53 & & 2604 & $41407098.71^{\mathrm{b}}$ \\
\hline
\end{tabular}

a Calculated based on $75 \%$ of the GDP per employee adjusted by the correction factor $(0.65)=11927.27$ euros / Obliczono na podstawie $75 \%$ PKB na 1 pracującego z uwzględnieniem współczynnika korygującego $(0,65)=11927,27$ euro.

${ }^{\mathrm{b}}$ Calculated based on the GDP per employee adjusted by the correction factor $(0.65)=15903.02$ euros / Obliczono na podstawie PKB na 1 pracującego z uwzględnieniem współczynnika korygującego $(0,65)=15$ 903,02 euro.

Other abbreviations as in Table 2 / Inne objaśnienia jak w tabeli 2.

and 2604 - with complete permanent disability (the CC caused workforce departure).

The total value of the production lost due to permanent disability was assessed to stand at $47743754.90 \mathrm{eu}-$ ros. The major reason for production losses was permanent disability in the form of workforce departure due to the invasive form of the CC (C.53) (Table 3).

3. Informal care givers' work absence - informal care givers devoted approx. 873 working days in 2012 to take care of the CC patients. The value of the produc- tion lost due to their work absence was assessed to stand at the level of 60638.17 euros (Table 4).

4. Mortality among the working age patient population - in 2012, 1669 women died in Poland due to the CC. All deaths were caused by the invasive form of the cervical cancer (C.53). The majority of women who died (998) were at the productive age, so it resulted in indirect costs of the lost production. Women's productive age is set at 18-67 years old (according to the Polish pension system principles). 
Table 4. Production lost due to informal care givers' work absence during providing care for cervical cancer (CC) patients in Poland, 2012

Tabela 4. Produkcja utracona z powodu opieki nad osobą chorą na nowotwór szyjki macicy w Polsce w 2012 r.

\begin{tabular}{|c|c|c|}
\hline $\begin{array}{l}\text { ICD-10 category } \\
\text { Kategoria ICD-10 }\end{array}$ & $\begin{array}{c}\text { Working days lost (approx.) } \\
\text { Utracone dni pracy (szacowane) } \\
{[\mathrm{n}]}\end{array}$ & $\begin{array}{c}\text { Production lost }{ }^{\mathrm{a}} \\
\text { Produkcja utracona } \\
\text { [EUR] }\end{array}$ \\
\hline C. 53 & 844 & 58615.69 \\
\hline D.06 & 29 & 2022.47 \\
\hline Total / Ogółem & 873 & 60638.17 \\
\hline
\end{tabular}

Abbreviations as in Table 1 and 2 / Objaśnienia jak w tabeli 1 i 2.

Table 5. Production lost due to deaths caused by cervical cancer (CC) in Poland, 2012

Tabela 5. Produkcja utracona z powodu zgonów spowodowanych nowotworem szyjki macicy w Polsce w 2012 r.

\begin{tabular}{|c|c|c|c|c|c|c|c|}
\hline $\begin{array}{l}\text { Year } \\
\text { Rok }\end{array}$ & $\begin{array}{l}\text { Women who would have } \\
\text { lived and been employed } \\
\text { if they had not died } \\
\text { due to CC, } 2012^{*} \\
\text { Kobiety, które } \\
\text { pozostałyby przy życiu } \\
\text { i były zatrudnione, } \\
\text { gdyby nie umarły } \\
\text { z powodu CC w } 2012 \text { r.* } \\
\text { [n] }\end{array}$ & $\begin{array}{c}\text { GDP per } \\
\text { employee’s } \\
\text { present value }{ }^{* *} \\
\text { Wartość } \\
\text { teraźniejsza } \\
\text { PKB na 1 } \\
\text { pracującego }^{* *} \\
\text { [EUR] }\end{array}$ & $\begin{array}{l}\text { Production } \\
\text { lost due } \\
\text { to mortality } \\
\text { Produkcja } \\
\text { utracona } \\
\text { z powodu } \\
\text { zgonów } \\
\text { [EUR] }\end{array}$ & $\begin{array}{l}\text { Year } \\
\text { Rok }\end{array}$ & $\begin{array}{l}\text { Women who would have } \\
\text { lived and been employed } \\
\text { if they had not died } \\
\text { due to CC, } 2012^{\star} \\
\text { Kobiety, które } \\
\text { pozostałyby przy życiu } \\
\text { i były zatrudnione, } \\
\text { gdyby nie umarly } \\
\text { z powodu CC w } 2012 \text { r.* } \\
\text { [n] }\end{array}$ & $\begin{array}{c}\text { GDP per } \\
\text { employee's } \\
\text { present value } \\
\text { Wartość } \\
\text { teraźniejsza } \\
\text { PKB na } 1 \\
\text { pracującego }^{* *} \\
\text { [EUR] }\end{array}$ & $\begin{array}{l}\text { Production } \\
\text { lost due } \\
\text { to mortality } \\
\text { Produkcja } \\
\text { utracona } \\
\text { z powodu } \\
\text { zgonów } \\
\text { [EUR] }\end{array}$ \\
\hline 2012 & 413 & 24466.19 & 6565271.77 & 2036 & 26 & 12887.10 & 216388.87 \\
\hline 2013 & 380 & 23853.37 & 5894794.02 & 2037 & 20 & 12543.44 & 162197.44 \\
\hline 2014 & 347 & 23253.63 & 5240757.39 & 2038 & 18 & 12208.95 & 142526.95 \\
\hline 2015 & 316 & 22666.75 & 4648871.54 & 2039 & 16 & 11883.38 & 123598.72 \\
\hline 2016 & 285 & 22092.52 & 4088954.38 & 2040 & 12 & 11566.49 & 92518.55 \\
\hline 2017 & 268 & 21530.74 & 3753952.43 & 2041 & 10 & 11253.64 & 75374.53 \\
\hline 2018 & 242 & 20981.20 & 3303753.36 & 2042 & 8 & 10944.97 & 56776.90 \\
\hline 2019 & 215 & 20443.68 & 2859284.93 & 2043 & 7 & 10640.60 & 49267.88 \\
\hline 2020 & 192 & 19917.98 & 2489693.68 & 2044 & 6 & 10340.63 & 42044.67 \\
\hline 2021 & 181 & 19402.01 & 2288414.93 & 2045 & 4 & 10045.19 & 27646.17 \\
\hline 2022 & 160 & 18895.71 & 1971026.06 & 2046 & 3 & 9756.27 & 19291.60 \\
\hline 2023 & 145 & 18399.03 & 1731454.43 & 2047 & 2 & 9473.80 & 11305.26 \\
\hline 2024 & 129 & 17911.89 & 1505800.60 & 2048 & 2 & 9197.71 & 11039.32 \\
\hline 2025 & 122 & 17434.24 & 1383614.56 & 2049 & 2 & 8927.91 & 10777.16 \\
\hline 2026 & 106 & 16966.01 & 1164252.52 & 2050 & 1 & 8664.32 & 3506.27 \\
\hline 2027 & 91 & 16507.12 & 980798.36 & 2051 & 1 & 8405.22 & 3420.77 \\
\hline 2028 & 81 & 16057.49 & 848833.06 & 2052 & 1 & 8150.66 & 3335.93 \\
\hline 2029 & 78 & 15617.06 & 792110.56 & 2053 & 1 & 7900.71 & 3251.82 \\
\hline 2030 & 68 & 15185.73 & 675338.95 & 2054 & 1 & 7655.41 & 3168.48 \\
\hline 2031 & 59 & 14769.21 & 563988.31 & 2055 & 0 & 7414.81 & 0.00 \\
\hline 2032 & 49 & 14366.92 & 453689.21 & Total / Ogółem & & & 55275508.11 \\
\hline 2033 & 44 & 13978.33 & 398068.72 & \multirow{3}{*}{\multicolumn{4}{|c|}{$\begin{array}{l}\text { GDP - as in Table } 2 \text { / PKB - jak w tabeli } 2 \text {. } \\
\text { * Adjusted by the forecast of the female employment rate / Skorygowane o prognozo- } \\
\text { wany wskaźnik zatrudnienia kobiet. } \\
{ }^{* *} \text { Adjusted by correction factor }(0.65) \text { / Z uwzględnieniem współczynnika korygu- } \\
\text { jącego }(0,65) \text {. }\end{array}$}} \\
\hline 2034 & 38 & 13602.91 & 337365.03 & & & & \\
\hline 2035 & 32 & 13240.17 & 277982.01 & & & & \\
\hline
\end{tabular}


The analysis of mortality-related production losses included the period 2012-2055, that is the year in which the last woman out of those who died in 2012 would have retired (if she had not died due to the CC). The outcomes are presented in the Table 5. In the calculation of the future production loss - the forecast of the women's employment rate per age group as well as the GDP growth was applied.
The total value of the production lost due to mortality among the working age patient population was assessed to stand at 55275508.11 euros and constitutes the main driver of the CC-related production loss.

\section{Summary results}

The Table 6 presents a summary of the outcomes. The total value of the 2012 CC morbidity and mortality-

Table 6. Reasons for production lost due to cervical cancer (CC) in Poland, 2012

Tabela 6. Przyczyny produkcji utraconej z powodu występowania nowotworu szyjki macicy w Polsce w 2012 r.

\begin{tabular}{lr}
\hline \multicolumn{1}{c}{$\begin{array}{c}\text { Reason } \\
\text { Przyczyna }\end{array}$} & $\begin{array}{c}\text { Production lost } \\
\text { Produkcja utracona }\end{array}$ \\
\cline { 2 - 2 } $\begin{array}{l}\text { Women's work absence related to temporary disability (sick leaves) / Czasowa niezdolność do pracy kobiet chorych } \\
\text { (zwolnienie lekarskie) }\end{array}$ & 8325193.85 \\
Women's work absence related to permanent disability / Trwała niezdolność do pracy kobiet chorych & 8.48 \\
Informal care givers' work absence / Nieobecność w pracy opiekunów osób chorych & 47743754.90 \\
Mortality among working age women / Zgony kobiet chorych w wieku produkcyjnym & 60638.17 \\
Total / Ogółem & 55275508.11 \\
\hline
\end{tabular}

Table 7. Sensitivity analysis of production lost due to cervical cancer (CC) in Poland, 2012

Tabela 7. Analiza wrażliwości produkcji utraconej z powodu występowania nowotworu szyjki macicy w Polsce w $2012 \mathrm{r}$.

\begin{tabular}{|c|c|c|c|}
\hline $\begin{array}{l}\text { Reason for production loss and discount rate } \\
\text { Przyczyna utraconej produkcji i stopa dyskontowa }\end{array}$ & \multicolumn{3}{|c|}{$\begin{array}{c}\text { Production lost } \\
\text { Produkcja utracona } \\
\text { [EUR] }\end{array}$} \\
\hline $\begin{array}{l}\text { Women' work absence related to temporary disability (sick leaves) / Czasowa } \\
\text { niezdolność do pracy kobiet chorych (zwolnienie lekarskie) }\end{array}$ & 8325193.85 & 7684794.33 & 7044394.80 \\
\hline $\begin{array}{l}\text { Women' work absence related to permanent disability / Trwała niezdolność do pracy } \\
\text { kobiet chorych }\end{array}$ & 47743754.90 & 44071158.37 & 40398561.84 \\
\hline $5 \%$ & 55275508.11 & 51023545.95 & 46771583.79 \\
\hline $3 \%$ & 63161753.86 & 58303157.41 & 53444560.96 \\
\hline $0 \%$ & 80163028.59 & 73996641.77 & 67830254.96 \\
\hline \multicolumn{4}{|l|}{ Discount rate (total) / Stopa dyskontowa (ogółem) } \\
\hline $5 \%$ & 111405095.03 & 102835472.34 & 94265849.65 \\
\hline $3 \%$ & 119291340.78 & 110115083.80 & 100938826.82 \\
\hline $0 \%$ & 136292615.51 & 125808568.16 & 115324520.82 \\
\hline
\end{tabular}


related production loss in Poland was assessed to stand at 111405095.04 euros. More than $66 \%$ of this value was attributed to women's mortality whilst the remaining value results from patients' morbidity, mainly work absence related to permanent disability to work (more than 25\%). The cervical cancer (CC) resulted in approx. 702964 working days lost in 2012 due to absence at work for both patients and care givers and a total number of 957678 working days lost due to patients' mortality.

\section{Sensitivity analysis}

The outcomes of the sensitivity analysis are presented in the Table 7. Depending on the GDP correction factor and the discount rate values, the total value of the production lost due to the CC morbidity and mortality in Poland in 2012 may range from 94 million euros (the lowest correction factor and the highest discount rate) to 136 million euros (the highest correction factor and a zero discount rate). Sensitivity analyses confirmed the robustness of the initial outcomes - in each case the mortality-related costs constituted the vast majority, whilst the total production loss value approximated the total amount of 115 million euros.

\section{DISCUSSION}

The calculation of production losses due to specific illness constitutes the basis of economic burden of disease studies and should also be included in health interventions' economic evaluation analysis conducted from a societal perspective. Application of the broad societal perspective when assessing the cost efficiency of a health intervention or program is perceived as a prerequisite for an allocative decision making process. Only the inclusion of all costs and consequences - regardless of whom they concern - will enable to calculate the net benefit for the society. In practice, however, the indirect costs of the lost production are often omitted in economic evaluation analyses, which may lead to misinterpretation of the actual costs and benefits, and consequently misinformation for the decision makers [25]. There are numerous difficulties and controversies related to the lost production costs calculation. Despite advances in research and numerous publications, there is still no consensus on the methodological approach to the indirect costs calculation.

In Poland, the application of the cost of illness studies and economic evaluation techniques to the decision making process within the health care sector is a rela- tively new process (the National Agency for Health Technology Assessment (Agencja Oceny Technologii Medycznych i Taryfikacji) was established in Poland in 2005). However, within the last decade its importance has been growing. The first analyses and recommendations on the calculation of the lost production due to specific illness in Polish settings have been published recently [26-28]. Researchers emphasize the importance of assessing the influence of health status on the ability to work, and thus, the economy in general.

The analysis of the annual production loss due to the cervical cancer morbidity and mortality in Poland - as presented in this paper - provides comprehensive information on the CC's influence on women's and care givers' ability to work and its overall economic burden for the society. The assessed value of the total production loss at the level of more than 111 million euros per year is almost 3 times higher than the total budget for prophylactics programs financed by the $\mathrm{Na}$ tional Health Fund (Narodowy Fundusz Zdrowia) (the main payers for the health care services in Poland), which in 2012 was at the level of 40 million euros. Even when diminishing the labour factor percentage share in the GDP (the sensitivity analysis), the value of the lost production is still enormous. The outcomes provide a significant incentive for Polish decision makers to intensify the CC prevention and screening actions.

Despite the overall reduction in the CC incidence and mortality rate in Poland within the last decade, the epidemiological indicators are still unsatisfactory (the mortality rate is one of the highest in Europe - 7.4 per 100000 population in 2012 in comparison with the average rate of 3.9 for the European Union countries) [1].

The high CC mortality in Poland is related to the problem of late diagnosis and a low attendance rate in population screening programs. A national population-based screening program had been launched in Poland in 2006 aiming at a target population of women aged 25-59. Only in 2012 personalized invitations had been sent to more than 3 million women, informing them about the importance of the regular CC screening and inviting them for free of charge cytology examination. Despite numerous additional promoting actions (happenings, conferences, education programs), the overall participation rate in the program is still low $-23.2 \%$ of the targeted population in 2012 [29]. Numerous studies indicate that one of the major problems of the CC prevention programs in Poland is insufficient level of knowledge and awareness among women [30-32]. 
Assessment of the production loss due to morbidity should provide a significant incentive for employers to promote and encourage women's participation in the screening programs. Our results indicate that in 2012 alone, the CC morbidity resulted in approx. 702964 working days lost due to absence from work of both patients and care givers. Workplace health promotion is becoming increasingly important in Poland. Numerous institutions (e.g., the National Centre for Workplace Health Promotion (Krajowe Centrum Promocji Zdrowia w Miejscu Pracy) and regional centers for occupational medicine) are involved in development and coordination of health education programs to be realized by employers, i.e., programs aimed at encouraging women to participate in the CC screening programs. In 2010 a proposal on changing legislation was made - aimed at the inclusion of cytology and mammography in the list of mandatory initial and periodic laboratory tests required by employers [33]. Unfortunately, the regulation was rejected.

\section{Study limitations}

Our analysis was influenced by several limitations caused mainly by insufficient data. The two major limitations relate to the exclusion of two additional categories of the potential lost production costs from the analysis - that is the presenteeism and unpaid work. These exclusions may lead to the underestimation of the total lost production value.

As for the presenteeism - there is no reliable data on how the CC influences a woman's productivity while she is present at work. Gathering such data would require an additional questionnaire-based study for the CC patients, which was not feasible within the scope of our study. Such a study was conducted in Poland by Macioch and Hermanowski in 2011 for all types of cancer patients [14]. The results showed that costs of the patients' presenteeism constituted approx. 17\% of those related to their absenteeism. Due to the lack of separate data for the CC patients (there was no information of whether they were included in the study population), those outcomes could not be extrapolated to our analysis.

The exclusion of unpaid work relates to retired women (calculation of mortality costs only for working age population) and those excluded from the official labour market (application of employment rate). Those exclusions are the consequence of the lack of reliable data and tools, validated for the Polish population, to measure the unpaid work value. It is emphasized in the literature that the issue of the lost production due to unpaid work needs further research and development of application guidelines [3]. The above limitations are direct results of the lack of reliable data and/or validated tools to gather them. As presented within our study, calculations are based on the published statistical data and macroeconomic factors. This provides a methodological framework which may be used in Polish settings for various diseases (enabling comparability of outcomes).

\section{CONCLUSIONS}

The analysis of the annual production loss due to the cervical cancer morbidity and mortality provides information on its influence on the population's ability to work and its overall economic burden for the society. The total value of the production lost due to the cervical cancer morbidity and mortality in Poland in 2012 was assessed to stand at the level of approx. 111 million euros. The outcomes should be used to inform decision makers and support allocative decisions. It is especially important to intensify the CC screening programs i.e., with employers' active involvement. Analyses of the production losses due to the CC should be carried out repeatedly based on standardized methodological guidelines and used as an evidence in health policy decision making process. In Poland a broad scope for potential improvements in the CC's epidemiological indicators exists and, as a consequence, reduced production losses.

\section{REFERENCES}

1. International Agency for Research on Cancer, World Health Organization [Internet]. Lyon: The Agency; 2012 [cited 2015 Mar 20]. Cervical cancer. Available from: http://eco.iarc.fr/EUCAN/CancerOne.aspx?Cancer $=25$ \&Gender $=2$.

2. [Demography database [Internet]. Warszawa: Central Statistical Office; 2014 [cited 2015 Jan 20]. Life expectancy tables 1990-2014]. Available from: http://demografia. stat.gov.pl/bazademografia/TrwanieZycia.aspx. Polish.

3. Krol M, Brouwer W, Rutten F. Productivity costs in economic evaluations: Past, present, future. PharmacoEconomics, 2013;31(7):537-49, http://dx.doi.org/10.1007/ s40273-013-0056-3.

4. Zhang W, Bansback N, Anis AH. Measuring and valuing productivity loss due to poor health: A critical review. Soc Sci Med. 2011;72(2):185-92, http://dx.doi.org/10.1016/ j.socscimed.2010.10.026. 
5. World Health Organization [Internet]. Geneva: The Organization; 2009 [cited 2015 Jan 20]. WHO guide to identifying the economic consequences of disease and injury. Available from: http://www.who.int/choice/ publications/d_economic_impact_guide.pdf.

6. Segel JE. Costs of illness studies - A primer [Internet]. RTI International, RTI-UNC Center of Excellence in Health Promotion Economic; 2006 [cited 2015 Jan 20]. Available from: https://www.rti.org/pubs/coi_primer.pdf.

7. Bradley CJ, Yabroff KR, Dahman B, Feurer EJ, Mariotto A, Brown ML. Productivity costs of cancer mortality in the United States: 2000-2020. J Natl Cancer Inst. 2008;100:1763-70, http://dx.doi.org/10.1093/ jnci/djn384.

8. Brown RE, Breugelmans JG, Theodoratou D, Bénard S. Costs of detection and treatment of cervical cancer, cervical dysplasia and genital warts in the UK. Curr Med Res Opin. 2006;22(4):663-70, http://dx.doi.org/10. 1185/030079906X99972.

9. Insinga RP. Annual productivity costs due to cervical cancer mortality in the United States. Womens Health Issues. 2006;16(5):236-42, http://dx.doi.org/10.1016/j.whi. 2006.06.005.

10. Insinga RP, Ye X, Singhal PK, Carides GW. Healthcare resource use and costs associated with cervical, vaginal and vulvar cancers in a large U.S. health plan. Gynecol Oncol. 2008;111(2):188-96, http://dx.doi.org/10.1016/ j.ygyno.2008.07.032.

11. Oliva J, Lobo F, Lopez-Bastida J, Zozayna N, Romay R. Indirect costs of cervical and breast cancers in Spain. Eur J Health Econ. 2005;6(4):309-13, http://dx.doi. org/10.1007/s10198-005-0303-4.

12. Ricciardi A, Largeron N, Giorgi Rossi P, Raffaele M, Cohet $\mathrm{C}$, Federici $\mathrm{A}$, et al. Incidence of invasive cervical cancer and direct costs associated with its management in Italy. Tumori. 2009;95(2):146-52.

13. American Cancer Society [Internet]. Atlanta: The Society; 2014 [cited 2015 Jan 20]. Cancer fact \& figures 2014. Available from: http://www.cancer.org/acs/groups/content/@ research/documents/webcontent/acspc-042151.pdf.

14. Macioch T, Hermanowski T. [Indirect costs of cancers in Poland in 2009. In: Hermanowski T, editor. Cost of illness assessment and its influence on labour activity and efficiency]. Warszawa: Wolters Kluwer; 2013. p. 181-211. Polish.

15. Hanly P, Timmons A, Walsh PM, Sharp L. Breast and prostate cancer productivity costs: A comparison of the human capital approach and the friction cost approach. Value Health 2012;15(3):429-36, http://dx.doi. org/10.1016/j.jval.2011.12.012.
16. Van den Hout WB. The value of productivity: Human-capital versus friction-cost method. Ann Rheum Dis. 2010;69 Suppl 1:i89-91, http://dx.doi.org/10.1136/ ard.2009.117150.

17. [Act of 11 May 2012 changing the bill on pensions and social security allowances from Social Insurance Fund and some other bills. J Laws 2012, item 637]. Polish.

18. European Commission. Directorate-General for Economic and Financial Affairs, Economic Policy Committee of the European Communities, Ageing Working Group. The 2012 ageing report: Underlying assumptions and projection methodologies. Luxembourg: The Commission; 2011.

19. [Central Statistical Office [Internet]. Warszawa: The Office; 2014 [cited 2015 Jan 20]. Labour force survey in Poland in the years 2010-2012]. Available from: http:// stat.gov.pl/obszary-tematyczne/rynek-pracy/pracujacybezrobotni-bierni-zawodowo-wg-bael/aktywnosc-ekonomiczna-ludnosci-polski-w-latach-2010-2012,5,3.html. Polish.

20. [Ministry of Health regulation of 2 April 2012 on minimal requirements for analysis submitted within the applications on refund and pricing (selling price and official price) of drugs, special nutrition products, medical products which does not have refunded equivalent in specific indication. J Laws 2012, item 388]. Polish.

21. European Commission. Directorate-General for Economic and Financial Affairs. What explains the difference in income and labour utilization and drives labour and economic growth in Europe? A GDP accounting perspective [Internet]. Brussels: The Commission; 2009 [cited 2015 Jan 20]. Available from: http://ec.europa.eu/ economy_finance/publications/publication13796_en.pdf.

22. European Commission. European Commission \& Directorate-General for Employment, Social Affairs and Equal Opportunities. Employment in Europe 2007. Luxembourg: The Commission; 2007.

23. Karabarbounis L, Neiman B. The global decline of the labor share [Internet]. Cambridge (MA): National Bureau of Economic Research; 2013 [cited 2015 Jan 20]. Available from: http://www.nber.org/papers/w19136.pdf.

24. Edejer T, Baltussen R, Adam T, Hutubessy R, Acharya A, Evans DB, et al., editors. Making choices in health: WHO guide to cost-effectiveness analysis. Geneva: The Organization; 2003.

25. Krol M, Brouwer W. How to estimate productivity costs in economic evaluations. PharmacoEconomics. 2014;32(4): 335-44, http://dx.doi.org/10.1007/s40273-014-0132-3.

26. Ernst \& Young Global Limited [Internet]. Warszawa: Ernst \& Young Global Limited; 2013 [cited 2015 Jan 20]. 
[Methods of indirect costs assessment in polish health care system]. Available from: http://www.ey.com/Publication/vwLUAssets/Raport_Metodyka_pomiaru_kosztow_posrednich_17.09/\$FILE/Raport_Metodyka\%20 pomiaru\%20kosztow\%20posrednich_17.09.pdf. Polish.

27. Hermanowski T, editor. [Cost of illness assessment and its influence on labour activity and efficiency]. Warszawa: Wolters Kluwer; 2013. Polish.

28. HTA Consulting \& INFARMA [Internet]. Warszawa: Infarma; 2014 [cited $2015 \mathrm{Feb}$ 20]. [Indirect costs in health technology assessment]. Available from: http:// www.infarma.pl/wiedza/raporty-infarmy/kosztypo\%C5\%9Brednie-w-ocenie-technologii-medycznych.metodyka,-badanie-pilotazowe-i-rekomendacje/. Polish.

29. [Minister of Health [Internet]. Warszawa: The Minister; 2014 [cited 2015 Jan 20]. Report on realization of National Program on reducing cancers in 2013]. Available from: http://www.mz.gov.pl/zdrowie-i-profilaktyka/ programy-zdrowotne/wykaz-programow/narodowy-program-zwalczania-chorob-nowotworowych/narodowyprogram-zwalczania-chorob-nowotworowych-na-lata2006-2015/. Polish.
30. Leszczyńska K, Franek G, Moskwa J, Nowak-Kapusta Z, Maciejewska-Paszek I, Irzyniec T. [Women's knowledge on cervical cancer prevention]. Zdrowie Dobrostan. 2015;2:257-70. Polish.

31. Pasławska A, Mrożek-Budzyn D, Majewska R. [Knowledge of young women concerning cytological screening in cervical cancer prevention]. Probl Hig Epidemiol. 2014;95(1):170-4 [cited 2015 Dec 1]. Available from: http://phie.pl/pdf/phe-2014/phe-2014-1-170.pdf. Polish.

32. Stefanek A, Durka P. [Women's knowledge of prevention of cervical cancer]. Pol Przegl Nauk Zdr. 2014;1(38): 29-38 [cited 2015 Dec 1]. Available from: http://www. przeglad.amp.edu.pl/uploads/2014/1/29_1_38_2014.pdf. Polish.

33. [Ministry of Health [Internet]. Warszawa: The Ministry; 2010 [cited 2015 Mar 13]. Project of the act on changing the bill on medical services financed from public sources and the bill on labour code of 20 April 2010]. Available from: http://bipold.mz.gov.pl/index?mr=m12091\&ms\&ml $=\mathrm{pl} \& \mathrm{mi}=209 \& \mathrm{mx}=0 \& \mathrm{mt}=\& \mathrm{my}=736 \& \mathrm{ma}=14988$. Polish.

This work is available in Open Access model and licensed under a Creative Commons Attribution-NonCommercial 3.0 Poland License / Ten utwór jest dostępny w modelu open access na licencji Creative Commons Uznanie autorstwa - Użycie niekomercyjne 3.0 Polska - http://creativecommons.org/ licenses/by-nc/3.0/pl/deed.en. 